found in great numbers in Roman deposits at several sites in the city, yet are absent from 8 th to 11 th century deposits, and reappear in the fossil record in the 12 th to 13 th century and later levels.

The Fishergate project is directed by Richard Kemp for the York Archaeological Trust, and is funded by English Heritage. I am grateful to Harty Kenward for comments on an earlier draft.

\title{
REFERENCES
}

Armitage, P., West, B. \& Steedman, K. (1984). New evidence of black rat in Roman London. London Archaeol. 4(14): 375383.

Corbet, G. B. \& Southern, H. N. (Eds) (1977). The handbook of British mammals. 2nd edn. Oxford: Blackwell. O'Connor, T. P. (1988). Bones from the General Accident site, Tanner Row. Archaeology of York 15(2): 61-136.

O'Connor, T. P. (1989). Bones from Anglo-Scandinavian levels at 16-22 Coppergate. Archaeology of York 15(3): $137-208$. Rackham, D. J. (1979). Rattus rattus. The introduction of the black rat into Britain. Antiquity 53: 112-120.

J. Zool., Lond. (1991) 224, 320-328

\section{Identification of fish otoliths and bones in faeces and digestive tracts of seals}

\author{
G. J. Pierce, P. R. Boyle and J. S. W. Diack, Department of Zoology, \\ University of Aberdeen, Tillydrone Avenue, Aberdeen AB9 2TN
}

\section{Introduction}

Diet analysis for seals is normally based on visual recognition of prey remains in digestive tracts or faeces. Thus, studies by Rae $(1960,1968,1973)$ were based on identification of hard remains of fish and invertebrates in stomach contents. More recent work has utilized identification and measurement of otoliths in faeces (e.g. McConnell et al., 1984; Prime \& Hammond, 1985; Härkönen, 1987, 1988; S.M.R.U., 1988).

Faecal and digestive tract samples present different kinds of problems in relation to the logistics of sample collection, the identification of prey remains, and the quantification of diet composition.

Faeces can only be collected on land, e.g. at breeding and haul-out sites, and sites may not be used by seals all year round (e.g. Thompson, 1989). Intertidal haul-out sites can be sampled only at low tide. Digestive tract samples can be collected at sea, but carcasses of pinnipeds often sink; e.g. two-thirds of sea-lions killed at sea by Fiscus \& Baines (1966) sank and could not be recovered. Another widely reported problem is that stomachs of seals killed on land are often empty (e.g. Pikharev, 1946; Kenyon, 1956), although the extent of this problem will vary seasonally, e.g. because some species fast during the breeding season. There are obviously also aesthetic, legal and moral issues associated with killing seals. Lavaging of stomach contents (e.g. Antonelis et al., 1987) potentially offers a non-destructive alternative.

The ease with which prey remains in digestive tract and faecal samples can be identified depends on the extent to which they have been degraded during ingestion and digestion. Only hard remains (e.g. fish otoliths and bones, cephalopod beaks) are likely to be identifiable in faeces; however, 
some hard parts are entirely digested and many are reduced in size during passage through the digestive tract (e.g. da Silva \& Neilson, 1985; Murie \& Lavigne, 1986; Jobling \& Breiby, 1986; Prime \& Hammond, 1987; Harvey, 1989). Differential passage rates are a potential source of bias when diet is assessed from stomach contents (Bigg \& Fawcett, 1985; Prime \& Hammond, 1987). Although many studies of diet have involved identification of fish bones (e.g. Hansel et al., 1988), the extent to which this increases the amount of information obtained from samples has not been evaluated.

There are several methods of quantifying diet composition, e.g. frequency of occurrence, numbers of prey, prey biomass: see Bigg \& Perez (1985) for a discussion of the biases associated with each. Estimation of prey biomass is normally based on measurements of fish otoliths and cephalopod beaks, corrected for reduction in size during passage through the digestive tract (e.g. Prime \& Hammond, 1987). However, some authors consider that the errors involved in this approach are so great that otoliths in faeces should not be used as the basis for quantification of diet (Jobling \& Breiby, 1986; Jobling, 1987).

In the present paper, digestive tract and faecal samples, from common seals (Phoca vitulina) and grey seals (Halichoerus grypus), collected in the course of a three-year study of the diets of seals in Scottish waters, are used to evaluate aspects of methodology. Specifically, we consider the logistics of collecting faecal samples, the proportion of digestive tract and faecal samples which contained identifiable prey remains, and the extent to which use of skeletal elements other than otoliths enhanced the information obtained from samples.

\section{Methods}

Digestive tract samples were supplied by the Department of Agriculture and Fisheries for Scotland (see Table I for details). In all cases, species was determined by examining the head or lower jaw (Corbet \& Southern, 1977). The digestive tracts were stored at $-20{ }^{\circ} \mathbf{C}$ prior to examination. Anecdotal information was obtained from fishermen on the success of attempts at recovering seals which had been shot.

TABLE I

Origin of digestive tract samples. All seals were taken from the east coast of Scotland between Helmsdale and Arbroath

\begin{tabular}{lcc}
\hline & \multicolumn{2}{c}{ Number of samples } \\
\cline { 2 - 3 } Source & $\begin{array}{c}\text { Common } \\
\text { seals }\end{array}$ & $\begin{array}{c}\text { Grey } \\
\text { seals }\end{array}$ \\
\hline Fishermen (in or near salmon nets) & 6 & $23^{1}$ \\
Fishermen (away from nets) & 4 & 2 \\
DAFS* (taken for tissue samples) & 0 & 15 \\
Found on beaches & 0 & $3^{2}$ \\
Total numbers of samples & 10 & 43 \\
\hline
\end{tabular}

\footnotetext{
* Department of Agriculture \& Fisheries for Scotland

Includes two samples of stomachs only

${ }^{2}$ Two of these animals were found injured and put down by vets
} 
TABLE II

Origins of faecal samples. Numbers of common seal scats $(C)$, grey seal scats $(G)$ and numbers of scats of unknown origin $(U)$ collected during each quarter of the year in each area, over the period June 1986 to February 1989. ('- 'indicates that the site was not visited.)

\begin{tabular}{lrrrrrrrrrrrrrrrr}
\hline Season & \multicolumn{1}{c}{ Jan.-Mar. } & \multicolumn{3}{c}{ Apr.-Jun. } & \multicolumn{3}{c}{ Jul.-Sep. } & \multicolumn{3}{c}{ Oct.-Dec. } & \multicolumn{3}{c}{ Totals } \\
\hline Location & $\mathrm{C}$ & $\mathrm{G}$ & $\mathrm{U}$ & $\mathrm{C}$ & $\mathrm{G}$ & $\mathrm{U}$ & $\mathrm{C}$ & $\mathrm{G}$ & $\mathrm{U}$ & $\mathrm{C}$ & $\mathrm{G}$ & $\mathrm{U}$ & $\mathrm{C}$ & $\mathrm{G}$ & $\mathrm{U}$ \\
Helmsdale & - & - & - & & 0 & 21 & 0 & - & - & - & - & - & - & 0 & 21 & 0 \\
Isle of May & 0 & 17 & 0 & - & - & - & - & - & - & 0 & 75 & 0 & 0 & 92 & 0 \\
Moray Firth & 83 & 0 & 1 & 54 & 11 & 36 & 129 & 1 & 31 & 41 & 0 & 0 & 307 & 12 & 68 \\
Orkney & 0 & 21 & 9 & 93 & 0 & 0 & 103 & 0 & 0 & 0 & 35 & 0 & 196 & 56 & 9 \\
Summer Isles & 0 & 62 & 0 & 0 & 0 & 0 & 0 & 0 & 0 & 0 & 0 & 0 & 0 & 62 & 0 \\
All areas & 83 & 100 & 10 & 147 & 32 & 36 & 232 & 1 & 31 & 41 & 110 & 0 & 503 & 243 & 77 \\
\hline
\end{tabular}

${ }^{1}$ Grey seal faeces were collected by DAFS at the Summer Isles in December, but were lost in transit

Faecal samples were collected at haul-out sites around Scotland (see Table II) during the period June 1986 to February 1989. Sites were visited at or around low tide and all faeces found were collected in polythene bags. When possible, seals using the haul-out were counted and identified to species before a collection was made. Samples were stored at $-20{ }^{\circ} \mathrm{C}$ prior to examination.

In the Moray Firth area faeces (primarily from common seals) were sampled during every month of 1988. Haul-out sites in the Beauly, Cromarty, Inverness and Dornoch Firths were visited by boat or on foot. Sampling by boat was attempted only in good weather conditions, to visit sites known to be used by common seals (Paul Thompson, pers. comm.). On each occasion, it was normally possible to visit sites in one Firth only.

Digestive tract samples were divided by ligatures into stomach, intestine and colon. The contents of each section were squeezed out and washed through a $0.355 \mathrm{~mm}$ sieve, to give separate samples for each section. All sections were then washed out into the sieve to recover any material adhering to the mucosa (residual washings). Faecal samples were also washed through a $0.355 \mathrm{~mm}$ sieve. All material remaining in the sieve was retained. All otoliths and a sample of bony remains were stored dry in glass vials. Cephalopod beaks and other invertebrate remains were stored in $95 \%$ ethanol.

A reference collection of otoliths and skeletons of North Sea fish was established. Between one and six specimens of 67 species were prepared. Flesh was softened by immersion in boiling water or cooking in a microwave oven. The bulk of flesh was removed and bones cleaned by soaking in a saturated solution of Bio-tex (Blumoller Ltd., Denmark). If necessary, fat was removed by soaking in a 50:50 mixture of acetone and chloroform. Skeletal elements were identified and stored dry in individually labelled containers.

Otoliths were identified using the reference collection and published otolith guides (Brodeur, 1979; Breiby, 1985; Härkönen, 1986). Other skeletal elements were identified using the reference collection. Bones which were recognizable to species and occurred in samples included the premaxilla, maxilla, dentary, articular, vomer, operculum, preoperculum, post-temporal, supracleithrum, cleithrum, hyal, urohyal, hyomandibular, palatine, otic capsules, teeth and denticles; also the atlas, ultimate and caudal vertebrae (see Ford, 1937; Norden, 1961 for terminology; Mujib, 1967). 
TABLE III

Success of faecal sampling in the Moray Firth area: Numbers of successful (i.e. $>0$ samples) and unsuccessful sampling trips, and average number of samples obtained in each quarter with standard deviation in parentheses

\begin{tabular}{lccccc}
\hline & \multicolumn{2}{c}{ Number of visits } & & \multicolumn{2}{c}{ Mean number of samples } \\
\cline { 2 - 3 } \cline { 6 - 6 } Quarter & Unsuccessful & Successful & & Per visit & Per successful visit \\
\hline Jan.-Mar. & 12 & 13 & & $3 \cdot 5(6 \cdot 5)$ & $6 \cdot 8(7 \cdot 6)$ \\
Apr.-Jun. & 6 & 17 & & $4 \cdot 5(4 \cdot 8)$ & $6 \cdot 1(4 \cdot 7)$ \\
Jul.-Sep. & 2 & 19 & & $7 \cdot 7(8 \cdot 0)$ & $8 \cdot 5(8 \cdot 0)$ \\
Oct.-Dec. & 3 & 10 & & $3 \cdot 2(4 \cdot 1)$ & $4 \cdot 1(4 \cdot 2)$ \\
Totals & 23 & 59 & & $4 \cdot 8(6 \cdot 4)$ & $6 \cdot 7(6 \cdot 7)$ \\
\hline
\end{tabular}

Results

\section{Sample collection}

Faeces were generally found as discrete units of solid or semi-solid material. In some cases several pieces of material were found along the track left by a seal moving towards the water, and were considered to be part of the same sample. Faecal material at the water's edge tended to have been broken up by wave action and was not included in the analyses.

Of 82 sampling trips in the Moray Firth area, faeces were found on 59 occasions ( $72 \%)$, with an average of 6.7 samples per 'successful' trip. Sampling trips were generally more successful in the summer than in the winter (see Table III). There was a significant positive relationship between the total number of seals present on haul-outs and the number of scats found (Spearman's rank correlation, $r=0.373, \mathrm{~N}=76$ trips, $P<0.01$ ).

Fishermen who supplied seal carcasses to DAFS reported, on several occasions, that seals shot near salmon nets or haul-out sites could not be recovered but were later found washed ashore. In one instance, of eight seals shot and killed in the water, only one could be recovered before it sank.

Identification of the species of seal which produced a faecal sample depends on information on the animals using a haul-out. Only grey seals were present at haul-outs on the Summer Isles and Isle of May. On Eynhallow in Orkney, both species were present but with different seasonal distributions. Both species are present in the Moray Firth, although grey seals occurred largely in the outer Dornoch Firth. At mixed haul-outs, identification of samples to species was necessarily tentative. Samples were recorded as of unknown origin if no seals were seen or if neither species comprised more than $90 \%$ of seals present.

\section{Presence of prey remains in samples}

Table IV summarizes information on the number of tracts containing recognizable food remains and the location of food remains in the digestive tracts. Most samples contained fish remains identifiable at least to Order (Table V). In many cases identification to species was possible.

Most faecal samples contained prey remains (Table V). However, up to $20 \%$ of grey seal faeces 
TABLE IV

Proportion of digestive tracts containing recognizable food remains. Negative results (i.e. the absence of prey remains from a given section) were included only if more than $90 \%$ of the otoliths recovered from the whole tract were recovered in separate sectional samples (i.e. $<10 \%$ otoliths in residual washings)

\begin{tabular}{lcc}
\hline Section & $\begin{array}{c}\text { Sample } \\
\text { size }\end{array}$ & $\begin{array}{c}\text { Containing prey } \\
\text { remains }\end{array}$ \\
\hline Stomach & 44 & $27(61 \cdot 4 \%)$ \\
Intestine & 42 & $29(69 \cdot 0 \%)$ \\
Colon & 48 & $43(89 \cdot 6 \%)$ \\
Entire tract & 51 & $48(94 \cdot 1 \%)$ \\
\hline
\end{tabular}

contained only fragments of fish bones which could not be identified further. Almost $95 \%$ of common seal samples contained fish remains identifiable at least to Order (and often to species).

There are two potential sources of error in otolith identification: loss of information due to failure to identify otoliths, and erroneous identification. The maximum loss of information due to failure to identify otoliths is given by the proportion of unidentified otoliths in the samples. In digestive tract samples, $99.7 \%$ of otoliths $(\mathrm{N}=6587)$ were identifiable at least to Order. For faecal samples the figures were: $99.9 \%(\mathrm{~N}=50792)$ for common seal samples, and $98.9 \%(\mathrm{~N}=6753)$ for grey seal samples. Identification to broad taxonomic groups is considered to be relatively

\section{TABLE V}

Categories of prey identification in digestive tract and faecal samples from common and grey seals. Note: fragments of mollusc shell were not counted as prey remains although frequently present, since they may originate from the substratum

\begin{tabular}{|c|c|c|}
\hline \multirow[b]{2}{*}{ Identification category } & \multicolumn{2}{|c|}{ Digestive tract samples } \\
\hline & $\begin{array}{l}\text { Common seals } \\
(\mathrm{N}=10)(\%)\end{array}$ & $\begin{array}{c}\text { Grey seals } \\
(\mathrm{N}=41)(\%)\end{array}$ \\
\hline $\begin{array}{l}\text { Prey present } \\
\text { Fish prey present } \\
\text { Fish identifiable at least to Order }\end{array}$ & $\begin{array}{l}70 \cdot 0 \\
70 \cdot 0 \\
70 \cdot 0\end{array}$ & $\begin{array}{r}100 \cdot 0 \\
97 \cdot 6 \\
90 \cdot 2\end{array}$ \\
\hline & \multicolumn{2}{|c|}{ Faecal samples } \\
\hline Identification category & $\begin{array}{l}\text { Common seals } \\
(\mathrm{N}=503)(\%)\end{array}$ & $\begin{array}{c}\text { Grey seals } \\
(\mathrm{N}=243)(\%)\end{array}$ \\
\hline Prey present & $98 \cdot 2$ & $98 \cdot 4$ \\
\hline Fish prey present & $98 \cdot 2$ & 98.4 \\
\hline Fish identifiable at least to Order & $94 \cdot 6$ & $79 \cdot 8$ \\
\hline
\end{tabular}




\section{TABLE VI}

Detection of otoliths and bones in seal digestive tract and faecal samples. Numbers of samples in which $(a)$ otoliths, $(b)$ bones, and (c) otoliths and/or bones of major prey groups were found, and the percentage of cases in which the prey would not have been detected using otoliths alone. Prey types occurring in fewer than five samples are not included in the table

\begin{tabular}{|c|c|c|c|c|}
\hline \multirow[b]{3}{*}{ Prey type } & \multicolumn{4}{|c|}{ Digestive tracts $(\mathrm{N}=53)$} \\
\hline & \multicolumn{3}{|c|}{ Number of samples } & \multirow{2}{*}{$\begin{array}{l}\text { Percentage of } \\
\text { identifications } \\
\text { relying on bones }\end{array}$} \\
\hline & Otoliths & Bones & Either & \\
\hline Clupeids & 5 & 3 & 5 & 0 \\
\hline Flatfish & 9 & 4 & 9 & 0 \\
\hline Gadids & 27 & 15 & 27 & 0 \\
\hline Lumpsuckers & 4 & 8 & 8 & 50 \\
\hline Salmonids & 3 & 5 & 6 & 50 \\
\hline \multirow[t]{3}{*}{ Sandeels } & 33 & 17 & 33 & 0 \\
\hline & \multicolumn{4}{|c|}{ Common seal faeces $(N=503)$} \\
\hline & \multicolumn{3}{|c|}{ Number of samples } & Percentage of \\
\hline Prey type & Otoliths & Bones & Either & relying on bones \\
\hline Clupeids & 98 & 134 & 155 & 37 \\
\hline Dragonets & 2 & 4 & 6 & 67 \\
\hline Flatfish & 37 & 30 & 48 & 23 \\
\hline Gadids & 84 & 67 & 112 & 25 \\
\hline \multirow[t]{3}{*}{ Sandeels } & 361 & 338 & 383 & 6 \\
\hline & \multicolumn{4}{|c|}{ Grey seal faeces $(N=243)$} \\
\hline & \multicolumn{3}{|c|}{ Number of samples } & Percentage of \\
\hline Prey type & Otoliths & Bones & Either & relying on bones \\
\hline Catfish & 1 & 11 & 11 & 91 \\
\hline Clupeids & 3 & 6 & 8 & 63 \\
\hline Dragonets & 6 & 8 & 10 & 40 \\
\hline Flatfish & 28 & 14 & 37 & 24 \\
\hline Gadids & 113 & 72 & 133 & 15 \\
\hline Lumpsuckers & 1 & 9 & 9 & 89 \\
\hline Sandeels & 97 & 79 & 110 & 12 \\
\hline
\end{tabular}

All faeces $(\mathrm{N}=823$, groups occurring in $<10$ samples excluded)

\begin{tabular}{lrrrr} 
& \multicolumn{2}{c}{ Number of samples } & $\begin{array}{c}\text { Percentage of } \\
\text { identifications }\end{array}$ \\
\cline { 2 - 4 } Prey type & Otoliths & Bones & Either & $\begin{array}{c}\text { relying on bones } \\
\text { relynn}\end{array}$ \\
\hline Catfish & 1 & 14 & 14 & 93 \\
Clupeids & 103 & 141 & 166 & 38 \\
Dragonets & 8 & 12 & 16 & 50 \\
Flatfish & 68 & 49 & 90 & 24 \\
Gadids & 210 & 147 & 262 & 20 \\
Lumpsuckers & 1 & 15 & 15 & 93 \\
Sandeels & 519 & 477 & 561 & 8 \\
\hline
\end{tabular}


straightforward and misidentification at this level should be negligible. Identification to species obviously requires greater discrimination and affords greater opportunity for error.

\section{Identification using skeletal remains other than otoliths}

In digestive tracts, most otoliths and many bones were intact. Of the most commonly occurring prey groups, clupeids, flatfish (Heterosomata), gadids and sandeels (Ammodytidae) were all detected more frequently from otoliths than from bones, and the overall frequency of occurrence was not increased by identifying bones. However, salmonid and lumpsucker (Cyclopterus lumpus) bones were found more frequently than otoliths, and use of bones increased the frequency of detection (see Table VI).

In faeces (Table VI), otoliths sometimes showed obvious signs of erosion but most were identifiable. Bones were often fragmented, but many fragments were identifiable. The frequency of detection of all the common prey groups was increased by using bones in addition to otoliths, particularly for fish with small or fragile otoliths. Some fish were identified primarily from a single type of bone: catfish (Anarhichas sp.) from teeth; dragonets (Callionymus lyra) from preopercular spines; lumpsuckers from denticles. Rajids (which lack otoliths) were identified from denticles in four scats.

\section{Discussion}

Digestive tract samples were obtained incidentally, and we therefore have little information on the practical problems involved in collecting samples. Anecdotal information from local fishermen did, however, support the observation that seals often sink when shot (e.g. Fiscus \& Baines, 1966); even when shot very close to land, carcasses were difficult to recover. Lavaging of stomach contents (e.g. Antonelis et al., 1987), which offers a non-destructive alternative, has not been widely applied to seals.

Although sampling effort was not uniform across all seasons, it was apparent that faeces could not be obtained all year round at all sites. This reflects seasonal changes in the use of sites by seals. Thus, for example, most grey seal breeding sites in Orkney are deserted during the summer (McConnell, 1985), and common seals in Orkney use different haul-out sites at different times of year (Thompson, 1989). Clearly, it is important to have information on seasonal movements of seal populations in order to obtain year-round information on diet.

Common seal faeces were obtained in the Moray Firth throughout 1988 but, although more than two-thirds of sampling attempts yielded at least one sample, mean sample size was low. Samples were more readily obtained in the summer months. An obvious (but by no means certain) method of increasing sampling efficiency would be to sample only when large numbers of seals are present at a site.

Examination of digestive tract samples from both species indicated that, although many had empty stomachs, most contained recognizable food remains in some part of the tract. Therefore, to maximize sampling efficiency, it is suggested that the contents of the entire digestive tract should always be examined in dietary studies. If lavaging is to be attempted, useful additional information could be obtained by sampling faecal material from the colon.

In digestive tract samples, identification of bones resulted in no increase in frequency of detection for most prey groups, reflecting the good state of preservation of otoliths. The two groups (lumpsuckers, salmonids) for which this was not the case ironically both have relatively 
friable skeletons. However, lumpsucker otoliths are very small and, at least in the case of seals feeding at salmon nets, salmon heads may not always be ingested (see, e.g. Rae \& Shearer, 1965).

In faeces many bones were broken or fragmented, but use of bones significantly increased the rate of detection for most fish groups. We have not here taken identification to species level: small sample sizes would then make comparisons difficult in any case. The precision of identification of both otoliths and bones depends on familiarity with reference material and as such can be continually improved.

No adequate keys exist for skeletal elements other than otoliths in dietary remains of piscivores, although some authors have demonstrated the value of particular bones for identifying certain prey species for particular predators (Wise, 1980; Hansel et al., 1988). Different fish are represented in seal scats by different bones, and it may therefore be inappropriate to concentrate entirely on a single type of bone (e.g. jaw or opercular bones) for all species. However, a given prey species may be reliably recognized from a single skeletal element.

The question arises as to whether use of bones in addition to otoliths would significantly alter estimates of diet composition in terms of fish biomass. Both bones and otoliths can be measured to estimate fish size (e.g. Casteel, 1976; Jobling \& Breiby, 1986; Prime \& Hammond, 1987; Hansel et al., 1988). The extent to which otoliths of a given fish species are reduced in size is quantifiable using captive feeding experiments (e.g. Prime \& Hammond, 1987; Harvey, 1989), although if the seals are inactive, passage rates may be reduced and digestion of otoliths increased (see Harvey, 1989). Although captive feeding experiments can be used to quantify the proportion of otoliths which are totally digested (e.g. da Silva \& Neilson, 1985; Murie \& Lavigne, 1986), obviously no meaningful correction factor can be applied when no otoliths are present in a field sample.

Some information is available on fish size-bone size relationships, e.g. in the archaeological literature (e.g. Casteel, 1976; Wheeler \& Jones, 1976), but reductions in bone size and loss of bones during digestion have not been quantified.

Measurements on selected bones in seal faeces and digestive tracts are likely to be useful for improving estimates of diet composition, particularly for species known to be under-represented from otoliths. Further work is needed, however, to establish appropriate fish size-bone size measurement for the targeted prey species, and to quantify size reduction and loss of bones passing through seal digestive tracts.

This work forms part of a joint project between the Department of Agriculture and Fisheries for Scotland, Aberdeen, and the University of Aberdeen, funded by the Scottish Office over the period 1/6/86 to 30/9/89. We thank everyone who assisted with sample collection and processing. P. Thompson and D. Miller coordinated collection of faecal samples in the Moray Firth area. D.A.F.S. organized provision of digestive tract samples. We thank an anonymous referee for helpful comments on the manuscript.

\section{REFERENCES}

Antonelis, G. A., Lowry, M. S., Demaster, D. P. \& Fiscus, C. H. (1987). Assessing northern elephant seal feeding habits by stomach lavage. Mar. Mamm. Sci. 3: 308-322.

Bigg, M. A. \& Fawcett, I. (1985). Two biases in diet determination of northern fur seals (Callorhinus ursinus). In Marine mammals and fisheries: 284-291. Beddington, J. R., Beverton, R. J. H. \& Lavigne, D. M. (Eds). London: George Allen \& Unwin.

Bigg, M. A. \& Perez, M. A. (1985). Modified volume: a frequency-volume method to assess marine mammal food habits. In Marine mammals and fisheries: 277-283. Beddington, J. R., Beverton, R. J. H. \& Lavigne, D. M. (Eds). London: George Allen \& Unwin. 
Breiby, A. (1985). Otolitter fra saltvannfisker i nord-norge. Tromura. Naturvitenskap nr. 45. Tromso: Universitetet $\mathrm{i}$ Tromso, Institutt for museumvirksomhet.

Brodeur, R. D. (1979). Guide to otoliths of some Northwest Atlantic Fishes. Massachusetts: National Marine Fisheries Service, Northeast Fisheries Center, Woods Hole Laboratory, Woods Hole.

Casteel. R. W. (1976). Fish remains in archaeology and paleo-environmental studies. London \& New York: Academic Press.

Corbet, G. B. \& Southern, H. N. (Eds) (1977). The handbook of British mammals. 2nd edn. Oxford: Blackwell.

da Silva, J. \& Neilson. J. D. (1985). Limitations of using otoliths recovered in scats to estimate prey consumption by seals. Can. J. Fish. aquat. Sci. 42: 1439 1442.

Fiscus, C. H. \& Baines, G. A. (1966). Food and feeding behavior of Steller and California sea-lions. J. Mammal. 47: 195200.

Ford, E. (1937). Vertebral variation in teleost fish. J. mar. biol. Ass. U.K. 22: 1-60.

Hansel, H. C., Duke, S. D., Lofy, P. T. \& Gray, G. A. (1988). Use of diagnostic bones to identify and estimate original lengths of ingested prey fishes. Trans. Am. Fish. Soc. 117: 55-62.

Härkönen, T. J. (1986). Guide to the otoliths of the bony fishes of the northeast Atlantic. Hellerup, Denmark: Danbiu.

Härkönen, T. J. (1987). Seasonal and regional variations in the feeding habits of the harbour seal, Phoca vitulina, in the Skagerrak and the Kattegat. J. Zool.. Lond. 213: 535-543.

Härkönen, T. J. (1988). Food-habitat relationship of harbour seals and black cormorants in Skagerrak and Kattegat. J. Zool., Lond. 214: 673-681.

Harvey. J. T. (1989). Assessment of errors associated with harbour seal (Phoca vitulina) faecal sampling. J. Zool., Lond. 219: $101-111$.

Jobling, M. (1987). Marine mammal faecal samples as indicators of prey importance- a source of error in bioenergetics studies. Sarsia 72: 255-260.

Jobling, M. \& Breiby, A. (1986). The use and abuse of fish otoliths in studies of feeding habits of marine piscivores. Sarsia 71: $265-274$

Kenyon, K.W. (1956). Food of fur seals taken on St Paul lsland, Alaska, 1954. J. Wildl. Mgm 20: 214-215.

McConnell, B. J. (1985). Seals in Orkney. Proc. R. Soc. Edinb. 87B: 95-104.

McConnell, B. J., Prime, J. H., Hiby, A. R. \& Harwood, J. (1984). Grey seal diet. In Interactions between grey seals and UK fisheries: 148-183. S.M.R.U. Report on research conducted for the Department of Agriculture and Fisheries Scotland by the Natural Environment Research Council's Sea Mammal Research Unit. Cambridge: N.E.R.C.

Mujib, K. A. (1967). The cranial osteology of the Gadidae. J. Fish. Res. Bd Can. 24: 1315-1375.

Murie, D. J. \& Lavigne, D. M. (1986). Interpretation of otoliths in stomach content analyses of phocid seals: quantifying fish consumption. Can. J. Zool. 64: 1152-1157.

Norden, C. R. (1961). Comparative osteology of representative salmonid fishes, with particular reference to the grayling (Thymallus arcticus) and its phylogeny. J. Fish. Res. Bd Can. 18: 679-791.

Pikharev, G. A. (1946). The food of the seal Phoca hispida. Fish. Res. Bd Can. (Transl. Ser.) 150: 1957.

Prime, J. H. \& Hammond, P.S. (1985). The diet of grey seals in the North Sea assessed from faecal analysis. In The impact of grey seals on North Sea resources: 84-99. Hammond, P. S. \& Harwood, J. (Eds). Report to the Commission of the European Communities on Contract ENV 665 UK(H). Cambridge: N.E.R.C.

Prime, J. H. \& Hammond, P. S. (1987). Quantitative assessment of gray seal diet from fecal analysis. In Approaches to marine mammal energetics: 165-182. Huntley, A. C., Costa, D. P., Worthy, G. A. J. \& Castellini, M. A. (Eds). Lawrence, Kansas: Society for Marine Mammalogy.

Rae, B. B. (1960). Seals and Scottish fisheries. Mar. Res. 1960 (2): 1-39.

Rae. B. B. (1968). The food of seals in Scottish waters. Mar. Res. 1968 (2): 1-23.

Rae, B. B. (1973). Further observations on the food of seals. J. Zool. Lond. 169: 287-297.

Rae, B. B. \& Shearer, W. M. (1965). Seal damage to salmon fisheries. Mar. Res. 1965 (2): 1-39.

S.M.R.U.(1988). Mutispecies fishery axsessment in the Norih Sea estimation of mortality caused by marine mammals. Final report on Contract with DGXIV-B-1 of the Commission of the European Communities. Cambridge: Sea Mammal Research Unit. Natural Environment Research Council.

Thompson, P. M. (1989). Seasonal changes in the distribution and composition of common seal (Phoca vitulina) haul-out groups. J. Zool., Lond. 217: 281-294.

Wheeler, A. \& Jones, A. (1976). Fish remains. In Excatations on Fuller's Hill, Great Yarmouth: 208-224. Rogerson, A. (Ed.). East Anglian Archaeology Report No. 2. Norfolk: Norfolk Archaeological Unit.

Wise, M. H. (1980). The use of fish vertebrae in scats for estimating prey size of otters and mink. J. Zool., Lond. 192: $25-31$. 


\section{Yellow-necked mice Apodemus flavicollis at Woodchester Park, 1968-1989}

D. W. Yalden, Department of Environmental Biology, University of Manchester M13 9PL R. F. Shore, I.T.E. Monks Wood, Abbots Ripton, Huntingdon PE17 2LS

The exceptional population of Yellow-necked mice Apodemus flavicollis occurring at Woodchester Park, Gloucestershire was first mentioned by Yalden (1971), who noted that on the grid studied there each June by students of Manchester University, A. flavicollis was twice as numerous as $A$. sylvaticus; generally, the wood mouse Apodemus sylvaticus is much more widespread and much more abundant in Britain than its congener. This abundance persisted to 1975 (Montgomery, 1976), and allowed the first substantial comparison of the ecology of the two Apodemus species in sympatry in Britain to be undertaken (Montgomery, 1977). In reviewing his own research and integrating it with the student studies, Montgomery (1985) pointed out that both the proportion and the absolute numbers of $A$. flavicollis on the main study grid declined after 1975. In this note, we bring the record for the main grid up to date, and also review the status of the species in the wider area of Woodchester Park.

\section{Study area and methods}

The main study grid, immediately below the field centre at Woodchester Park (Nat. Grid Ref. SO 811012 ), is a steeply sloping area of 0.77 ha (an effective trapping area, including boundary strips half a home range wide, of about 1.73 ha; Yalden, 1971). It is in mixed deciduous woodland, principally of Fraxinus, Fagus and Taxus, part of a continuous cover of woodland along the steep slopes of both sides of the valley. Much of the deciduous woodland has, however, been felled in the last 25 years, to be replaced by Larix, Fagus, Thuja and other commercial species. A fuller description of the valley is given by Askew \& Yalden (1985).

In the early years, the size of the grid and the number of traps varied somewhat (Montgomery, 1976), but has been constant at 96 traps set at $10 \mathrm{~m}$ intervals ( $8 \times 12$ rows) since 1976 . This is Grid $\mathrm{M}$ of Montgomery $(1977,1985)$. In June 1989, we laid 10 trap lines, each of 10 pairs of traps at $20 \mathrm{~m}$ intervals, in various sites around the valley; these sites were chosen, mostly, because they yielded A. flavicollis in earlier years. They were each set for four nights, as was the main grid. Individuals were marked by fur clipping; in the following analysis, the numbers of individuals handled at each site (rather than calculated populations) are used, for ease of comparison over the years. This procedure may underestimate the presence of bank voles Clethrionomys glareolus, which seem somewhat more 'trap-shy' than the Apodemus spp. (Montgomery, 1985).

\section{Results}

Main grid. In the years 1968-1975, A. flavicollis was generally twice as numerous as A. sylvaticus, and in six out of eight years was the most numerous woodland rodent ( $C$. glareolus outnumbered it in 1968 and 1971). Numbers of $A$. sylvaticus and A. flavicollis were positively related, however 